\title{
Evaluation of calcium cyanamide addition during co-composting of manure and maize straw in a forced-aeration static-pile system
}

\author{
Huasai Simujide ${ }^{1}$, Chen Aorigele ${ }^{1 *}$, Chun-Jie Wang ${ }^{2}$, Tian-Hua Zhang ${ }^{1}$ and Bai Manda ${ }^{1}$
}

\begin{abstract}
Background: Composting is one of the most environmentally friendly treatments to inactivate pathogenic organisms or reduce them to acceptable levels. However, even under thermal conditions, some pathogenic organisms such as $E$. coli could exist for a long time in composting. Such great persistence may increase the possibility of outbreaks of these organisms and further increase the environmental load. Calcium cyanamide $\left(\mathrm{CaCN}_{2}\right)$ has recently been recognized to have the fungicidal effect on the pathogens of the soilborne diseases. So, the present study determined the effect of $\mathrm{CaCN}_{2}$ addition on composting progress as an antimicrobial agent and an amendment during forcedaeration static-pile composting of cow manure, which was mainly aimed to inhibit the pathogens that had not been inactivated by heat during composting.

Methods: The mixtures of dairy cow manure and maize straw with addition of $2 \% \mathrm{CaCN}_{2}$ or no addition were composted for 63 days. The physical, chemical and biological changes in compost mixtures were examined during composting. The data were statistically analyzed using ANOVA procedure from SAS software (version 9.0).

Results: The results showed that the addition of $\mathrm{CaCN}_{2}$ significantly increased the maximum temperature and lengthened the duration of the thermophilic phase, and increased the percent T-N but decreased C/N ratio. For microbiological test, the addition of $\mathrm{CaCN}_{2}$ shortened the time to inactivate $E$. coli, and increased the total average population of thermophilic bacteria but did not significantly influence that of mesophilic bacteria.

Conclusion: The results indicated that the addition of $\mathrm{CaCN}_{2}$, at least at the additive content of $2 \%$ could benefit the thermophilic phase and the composting could quickly reach the sanitary standard during the composting of manure with maize straw in a forced-aeration static-pile system. This finding will contribute to solve the feces disposal problems.
\end{abstract}

Keywords: Calcium cyanamide, Antimicrobial agent, Manure, Composting, Pathogen

\section{Background}

Cattle manure, a valuable resource because of its nutrient and organic matter contents, is used as a soil fertilizer and represents a low-cost alternative to mineral fertilizers [1]. However, if the appropriate treatment methods are not carried out, manures would become solid wastes rather than valued resources. Serious environmental problems, such as an excessive input of potentially harmful trace

\footnotetext{
*Correspondence: aori6009@163.com

${ }^{1}$ College of Animal Science, Inner Mongolia Agricultural University,

Zhaowuda road, 306, 010018 Hohhot, China

Full list of author information is available at the end of the article
}

metals, inorganic salts and animal pathogens would develop because of inappropriate disposal practices $[2,3]$.

Composting is not only the most efficient process to produce an agronomically advantageous soil organic amendment, but also one of the most environmentally friendly treatments to inactivate pathogenic organisms or reduce them to acceptable levels $[4,5]$. Minimally managed composting processes can reduce E. coli and other pathogens in bovine manure [6, 7]. But the survival of the pathogens is greatly different in different systems, for example, in some composting systems even under thermal conditions, some strains of pathogens could exist for a long time or recover after some days. 
Such persistence increases the likelihood of disease outbreak and further increases the environmental load. Therefore, it is necessary to produce more reliable and realistic methods feasible in both sanitation and recycling of manure.

Calcium cyanamide $\left(\mathrm{CaCN}_{2}\right)$ has mostly been used as a nitrogen fertilizer for a long time. However, some studies have found its fungicidal effect on the pathogens of the soilborne diseases. The $\mathrm{CaCN}_{2}$ effectively suppressed Fusarium solani f.sp. cucurbitae in greenhouse cucumber [8], and was also fungicidal to Fusarium oxysporum f.sp. Cucumberinum [9]. However, very little is known about its effect on zoonotic microorganisms. Our previous study showed that manure composting would quickly reach the sanitary standard and the quality of the composting products would be improved with the addition of $\mathrm{CaCN}_{2}$ during mesophilic composting at laboratory scale [10]. On the basis of previous work, the present research further studied the effect of $\mathrm{CaCN}_{2}$ addition on minimally managed composting progress during co-composting of manure and maize straw in a forced-aeration static-pile system. The evaluation of $\mathrm{CaCN}_{2}$ effect in different composting system will allow us to broaden our knowledge about its use in composting. Therefore, the two major objectives of this study were (a) to assess the antimicrobial effect of $\mathrm{CaCN}_{2}$ during the minimally composting of cattle manure with maize straw and (b) to evaluate its effect on composting process as an amendment during the minimally composting of cattle manure with maize straw.

\section{Methods}

\section{Experimental design}

Composting trial was conducted on a cow farm of Inner Mongolia Autonomous Region of China in autumn (from September to mid-November). Fresh manure of dairy cows which were apparently healthy but had been confirmed to carry pathogenic $E$. coli with serogroups of O1, O6, O8, O9, O78, $\mathrm{O} 98$ and $\mathrm{O} 149$ in their gastrointestinal tracts was collected and mixed with maize straw (bulking agent). Composting was conducted on a concrete apron, subdivided into two separate compartments, each with floor dimensions $120 \times 120 \mathrm{~cm}$. Compartments were isolated from each other by $120 \mathrm{~cm}$ high walls, and were all unroofed. Perforated polyvinylchloride (PVC) pipes segregated from the compost piles by closely spaced parallel boards were used at the bottom of compartments to supply adequate oxygen (supplied by a blower), and to maintain uniform mixing. The air supply was provided from the 4th day of the composting. The air-flow rate was $0.5 \mathrm{~m}^{3} \cdot \mathrm{min}^{-1}$ during the first 2 weeks and then became $0.25 \mathrm{~m}^{3} \cdot \mathrm{min}^{-1}$. Maize straw was laid $5 \mathrm{~cm}$ thick over the boards in order to distribute air equally. And to ensure that all areas of the compostable material were exposed to the required temperature, each pile was covered with a plastic film. Compost piles contained about $500 \mathrm{~kg}$ compostable mixtures per compartment at the beginning of each experiment, and were maintained in a roughly conical shape during composting. The piles were classified into test pile and control pile. Solid $\mathrm{CaCN}_{2}$ was thoroughly mixed with the test pile at the mixing rate of $2 \%$ by weight, while was not added to the control pile. The mixing rate was based on the previous study, which had showed that manure composting process would not be influenced by the addition of both 2 and $3 \% \mathrm{CaCN}_{2}$ during mesophilic composting at laboratory scale [10]. Compost samples in duplicate were collected from each pile by using quartering process at days $0,1,3,4,9,14,21,28,35,42,49,56$, and 63 for the analysis of different parameters.

\section{Physico-chemical analysis}

Ambient temperature around the compost bins and temperatures within each pile was measured daily at 9:00 AM and 15:00 PM. Daily temperature of the pile was the average temperature of the top, middle and bottom layer in the two measurements. The moisture contents of the samples were determined after oven drying at $105{ }^{\circ} \mathrm{C}$ to a constant weight [11]. The $\mathrm{pH}$ was determined by a Mettler-Toledo EL20 pH-meter (Mettler-Toledo international trading (Shanghai) Co., Ltd.). Total nitrogen (T-N) and total carbon (T-C) was measured by kjeldahl method and $\mathrm{K}_{2} \mathrm{Cr}_{2} \mathrm{O}_{7}$ volumetric method [11]. Total phosphorus (T-P) was recovered by sulfuric acidhydrogen peroxide digestion according to Chinese national standard NY/T 298-1995.

\section{Seed germination test}

Seed germination test was carried out on filter paper lined in petri dishes [12]. Aqueous extract from the composting samples was prepared by shaking for $1 \mathrm{~h}$ at a solid: $\mathrm{H}_{2} \mathrm{O}$ ratio of 1:8 (w/v, dry weight basis). $5.0 \mathrm{~mL}$ each extract was pipetted into a petri dish, and 10 seeds of Chinese cabbage (Brassica campestris ssp. pekinensis) were evenly placed on the filter paper and incubated at $25{ }^{\circ} \mathrm{C}$ for $48 \mathrm{~h}$ in darkness. $\mathrm{H}_{2} \mathrm{O}$ was used as an extract of the controls. Each sample was analyzed in quintuplicate. A formula for calculating germination index (GI) was as follows [13]:

$$
G I(\%)=\frac{\text { seed germination } \times \text { root length of test pile }}{\text { seed germination } \times \text { root length of control pile }} \times 100 \%
$$

\section{Microbiological analysis}

Plate counting was performed to determine the populations of fecal indicator bacteria E. coli, thermophilic (TB) and mesophilic bacteria (MB) within compost piles. E. coli was investigated from eosin-methylene blue agar 
(EMB) plates and confirmed by Indole Test [14]. Mesophilic and thermophilic bacteria were enumerated on nutrient agar after incubating for $24 \mathrm{~h}$ at 30 and $50{ }^{\circ} \mathrm{C}$, respectively.

\section{Results and discussion}

\section{Physical and chemical analyses}

Using the aerobic thermophilic composting method, operating conditions of $50-55{ }^{\circ} \mathrm{C}$ or greater for 5 to 7 days are recommended by the national sanitary standard [15]. In this trial, the test pile reached temperatures $>55{ }^{\circ} \mathrm{C}$ for 19 days and $>50{ }^{\circ} \mathrm{C}$ for 23 days while the control pile recorded lower temperatures which were $>50{ }^{\circ} \mathrm{C}$ for 9 days when the maximum temperature was only $55^{\circ} \mathrm{C}$ at 23 days (Fig. 1). The maximum temperature of $65.5^{\circ} \mathrm{C}$ was reached at 29 days for the test pile.

Some studies suggested the temperatures of 55 to $60{ }^{\circ} \mathrm{C}$ for 7 to 14 days as the ideal temperatures for effective composting [16-18]. However, others reported that lower temperatures were still efficient to inactivate bacterial populations such as E. coli, the temperatures included $45^{\circ} \mathrm{C}$ for $72 \mathrm{~h}$ in a study conducted by Lung et al. [19] and 33.5 to $41.5^{\circ} \mathrm{C}$ for 7 days by Larney et al. [20]. In our previous study [10], pathogenic E. coli with different serotypes were all effectively eliminated during mesophilic composting (peak temperatures $39.0-41.1{ }^{\circ} \mathrm{C}$ ). On the other hand, the changes in composting temperature during composting are influenced by some factors including compostable materials and composting method. Changa et al. [21] found that the composting temperature reached $60{ }^{\circ} \mathrm{C}$ within 10 days during composting of cattle manure blended with a mixture of sawdust and wood shavings, while it was still be around $30{ }^{\circ} \mathrm{C}$ for 10 week during composting of the same dairy manure blended with wheat straw and reached a higher level after 6 weeks for hog manure composting. Fuentes et al. [22] reported that the composting temperature rose to about $40{ }^{\circ} \mathrm{C}$ within the fist 20 days and kept $43-51{ }^{\circ} \mathrm{C}$ at next coming 20 days, and then decreased rapidly and maintained $23 \pm 2{ }^{\circ} \mathrm{C}$ to the end during aerobic degradation of dairy cattle dung in laboratory-scale reactors for 105 days. In the current study, as shown in Fig. 2, the peak temperatures were achieved at 23 days in the control pile and 29 days in the test pile, indicating that the time to reach the high temperatures was delayed with the addition of $\mathrm{CaCN}_{2}$ which was in accordance with our previous laboratory-scale composting studies, and it is always associated with reduced porosity of the composting piles in the beginning. However, the maximum temperature in the test pile was much higher than the control pile, and the duration of high temperatures was also much longer in the former.

The moisture contents of all piles presented the same changes that followed a declining trend. The mean moisture content of the test pile decreased from an initial value of 70.97 to $60.71 \%$. In the control pile, it decreased from 75.28 to $58.86 \%$. Water availability is a critical determinant of microbial activity during composting [23]. Several studies reported that the moisture content in fed-batch composting of household biowaste was 30-40 \%, at which the microorganisms showed the highest protease activity [24, 25]. Nelson et al. [26] suggested a possible threshold between 50 and $60 \%$ moisture content during cattle manure composting, which has a potential to achieve the best temperature profile and save the energy required to turn the windrows. Many other observations also recommended $50-60 \%$ as the preferred moisture content range during composting [27-29]. Klasse [30] pointed out that the moisture content was one of the important determinants of the decomposition efficiency of $\mathrm{CaCN}_{2}$ in soil. Our previous study showed that the elimination of pathogenic E. coli by $\mathrm{CaCN}_{2}$ during manure composting was most effective in $85 \%$ moisture content condition and was followed by in $65 \%$. In $45 \%$ moisture content, pathogenic E. coli could not be thoroughly inactivated. Based on such result, we aimed to adjust the moisture content of the test

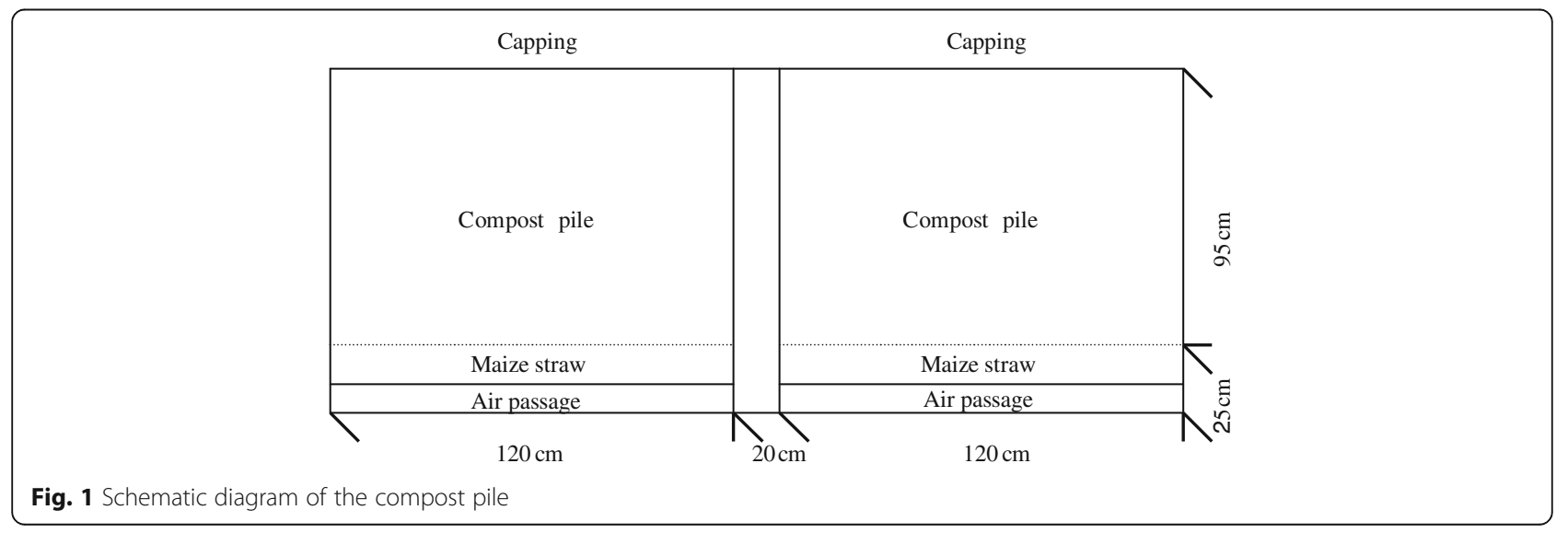




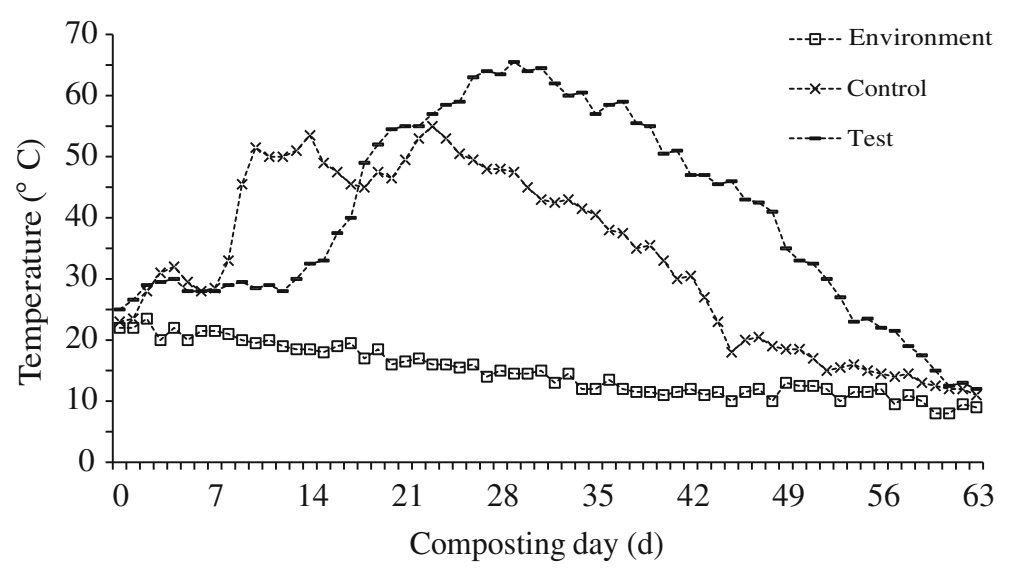

Fig. 2 The temperature profile during composting

pile to $70 \%$ to guarantee both a smooth process for composting and better development for inhibitory effect of $\mathrm{CaCN}_{2}$ on E. coli.

Due to the decomposition of organic matter and production of organic and inorganic acids by the activities of microorganisms, the $\mathrm{pH}$ usually decreases at the beginning of composting process, followed by a significant increase with the temperature increases and then decreases during the late stage [31]. The changes in $\mathrm{pH}$ in this study showed a similar trend (Fig. 3). A slight decrease in $\mathrm{pH}$ occurred at the beginning of composting. This can be explained by a lack of oxygen that may occur at the beginning of composting which would result in the production of acids [32]. The $\mathrm{pH} 8-9$ is known to be a crucial factor during successful composting and in matured compost [33]. Low $\mathrm{pH}$ acts as an inhibiting factor for microbial activity in composting process $[34,35]$. In this test, the $\mathrm{pH}$ fluctuated from 8.02 to 8.95 in the test pile and from 8.01 to 8.98 in the control test during the process (Fig. 3). This implied that both of the two piles were in good physical state and able to facilitate composting [36].

Trends in percent T-C for the two piles revealed significant losses in T-C during composting, which was resulted from the constant decomposition of carboncontaining organic substances in compost piles. Percent $\mathrm{T}-\mathrm{C}$ for the test pile decreased from an initial mean value of 49.66 to $33.90 \%$ at the end of composting representing a loss of $31.74 \%$ of the initial level, when it was from 42.12 to $35.00 \%$ in the control pile which represented a loss of $16.90 \%$ of the initial value. The changes in percent T-N generally showed an increasing trend. The percent $\mathrm{T}-\mathrm{N}$ in the test pile increased from an initial value of 1.25 to $2.59 \%$ at the end (Fig. 4). The mean values of total percent $\mathrm{T}-\mathrm{N}$ in the control pile were significantly lower than the test pile and increased from an initial value of 1.06 to $1.44 \%$ at the end of composting. Compostable materials mixed to provide a $\mathrm{C} / \mathrm{N}$ ranged from 25 to 30 are considered ideal for organic compounds degradation. However, larger ranges have been reported to be acceptable in some studies [37, 38]. Michel et al. [39] suggested that the initial $\mathrm{C} / \mathrm{N}$ ratio should be greater than 40 during the composting of dairy manure amended with sawdust or straw in order to effectively reduce the $\mathrm{N}$ loss. In the present study, the initial values of $\mathrm{C} / \mathrm{N}$ ratio were 39.73 in the test pile and 39.73 in the control pile (Fig. 4). Then, the $\mathrm{C} / \mathrm{N}$ ratio in both piles showed a significant declining trend. During composting, the relative concentration of T-N always increases due to the constant loss of organic matter. Therefore, $\mathrm{C} / \mathrm{N}$ ratio also constantly declines. At the end of composting, the mean value of $\mathrm{C} / \mathrm{N}$ ratio was 13.09 for the test pile which was significantly lower than that of 24.31 in the control pile.

The changes in T-P of each pile followed the same trend with a subtle decline in the early days, and then an obvious recovery and increase until the end of the experiment (Fig. 5). This indicates that the decomposition of $\mathrm{P}$ primarily occurred in the mesophilic phase. The finding is in

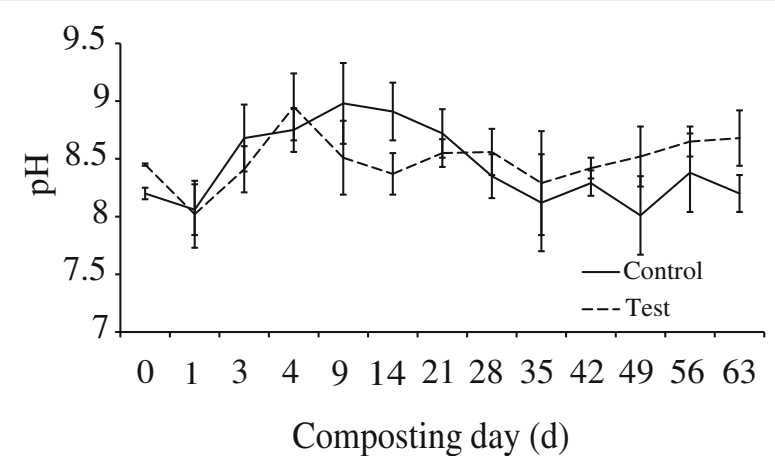

Fig. 3 The $\mathrm{pH}$ profile during composting 


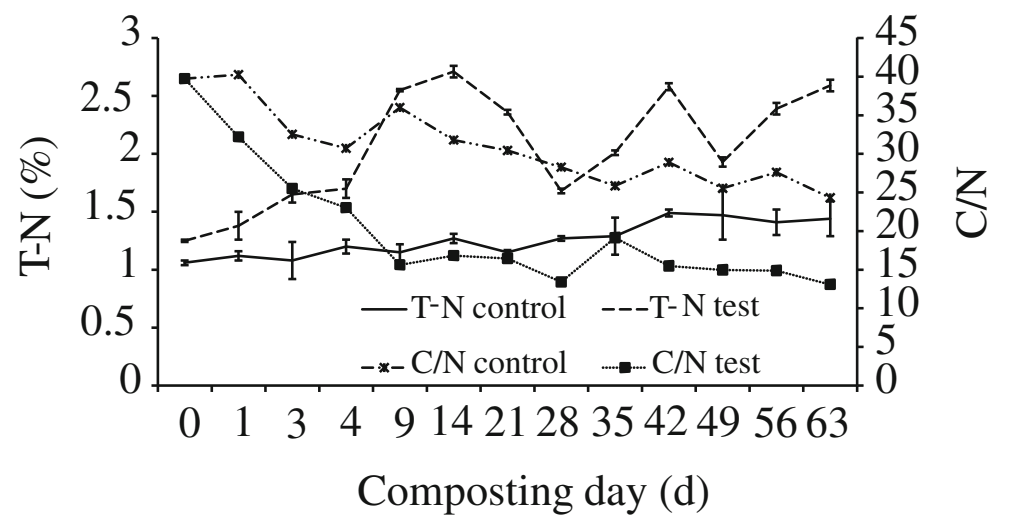

Fig. 4 The $T-N$ and $C / N$ profile during composting

accordance with the results of Zhang and He [40]. Parkinson et al. [41] reported that the T-P concentrations were elevated whether in turned or static manure composting at the end of all experiments conducted for a minimum of four months. In the present study, the mean T-P content of the test pile increased from an initial value of $3.39 \mathrm{~g} \cdot \mathrm{kg}$ ${ }^{-1}$ to $4.70 \mathrm{~g} \cdot \mathrm{kg}^{-1}$ after the whole period of composting and the increasing rate was $38.64 \%$. In the control pile, it


creasing rate of $30.59 \%$. The increasing change in T-P is caused by dry matter loss and the gradational content of manure in each pile was responsible for the T-P grads throughout the composting $[40,41]$.

\section{Phytotoxicity assay}

The potential agronomic value of the end product of the compost and its suitability for plant crops must be considered for management of the composting process by evaluating its degree of maturity [1]. Seed germination test is one of the biological methods used to evaluate the maturity of compost. Germination index (GI) was determined in both piles (Fig. 6). The control pile gave a GI of $65.05 \%$ at the initial stage of composting, which exceeded the threshold limit of $60 \%$ stated by Zucconi and de Bertoldi [42] to reduce the phytotoxicity to levels consistent with a safe soil application. For the test pile, the GI was $0 \%$ in the initial days. Then, after the 14 days of composting, there was a significant increase in the GI and it exceeded the threshold limit from 21 days. The GI reached its highest value during the cooling phase for both piles, although significant increases occurred from the thermophilic phase; at the end of composting, this index underwent a slight depression. El Fels et al. [32] reported a similar result by composting two species mixtures (co-composting of sewage sludge-lignocelullosic waste).

At the first stage of composting, the values of the GI are often low because of the inhibitory effect of excessive $\mathrm{NH}_{4}^{+}$on the seed germination, but the GI always follows an increasing trend with the proceeding of composting [43]. The result of our current and previous study showed a similar trend [10]. The high value of the GI from the thermophilic phase can be explained by a great

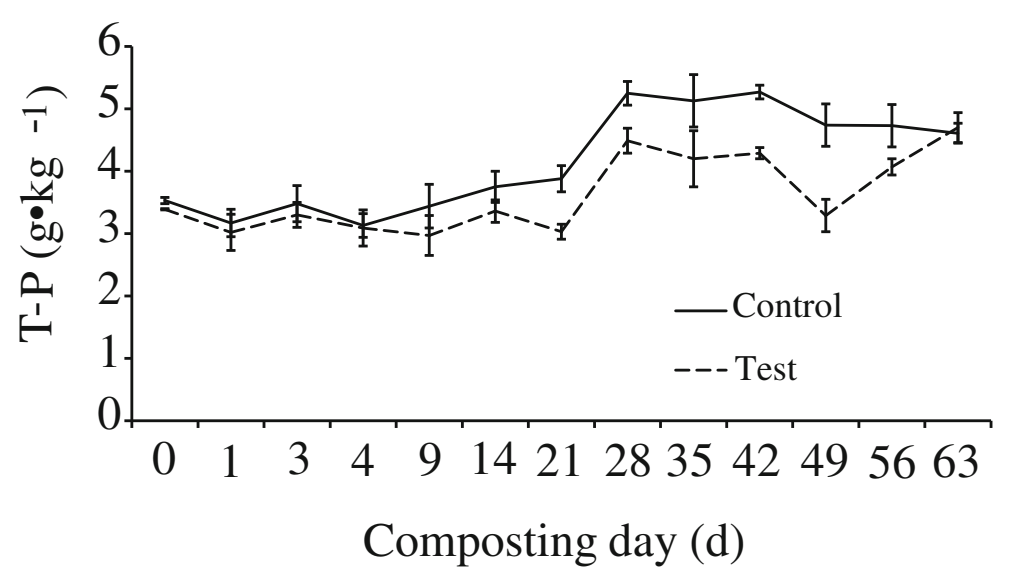

Fig. 5 The T-P profile during composting 


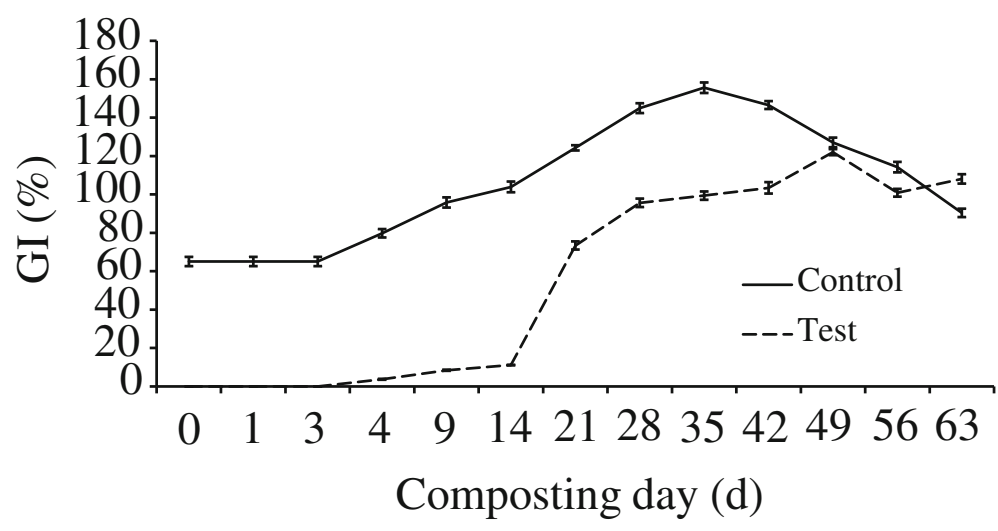

Fig. 6 The Gl profile during composting

reduction of phytotoxic substances. During the cooling phase, the GI continues to increase and generally obtains its highest value with the occurrence of stable organic matter, and the enrichment of humic substances and nutrients [42]. The fall of the GI at the end of composting can be partly explained by the action of phytotoxic substances, and by the high ionic charge of the watersoluble extracts and their electrical conductivity which may cause osmotic effects. This effect is caused particularly by the concentration of mineral elements such as $\mathrm{Cu}$ and $\mathrm{Zn}$, which showed an inhibitory effect on germination [32, 44].

\section{Microbiological analysis}

\section{E. coli}

Our previous works showed that the E. coli and other pathogens could be entirely killed with the addition of $\mathrm{CaCN}_{2}$ in the cow manure composting $[10,45]$. And all of the tested $E$. coli strains with different types of serogroups were quickly inactivated in the compost piles added $\mathrm{CaCN}_{2}$ [10]. The present study further confirmed such effect during a forced-aeration static-pile system in which maize straw was a bulking agent. As shown in Fig. 7, the E. coli was not thoroughly detected from 21 days in the test pile when from 28 days in the control pile. The addition of $\mathrm{CaCN}_{2}$ shortened the time to inactivate $E$. coli in the compost pile.

\section{Mesophilic and thermophilic bacteria}

At the first stage of composting, mesophilic microbial community converts easily degradable substrates and this activity increases temperature [46]. As temperature rise and exceed the tolerance limit of mesophilic microorganisms, thermophilic microorganisms dominate the microbial community [47, 48]. In this study, the development trend of the mesophilic and thermophilic bacteria was similar in both piles (Fig. 8) and was in agreement with the works of the above authors. With the addition of $\mathrm{CaCN}_{2}$, the initial population of mesophilic and thermophilic bacteria fluctuated slightly, but not significantly. At the end of composting, the population decreased by 58.67 and $31.51 \%$ for mesophilic bacteria

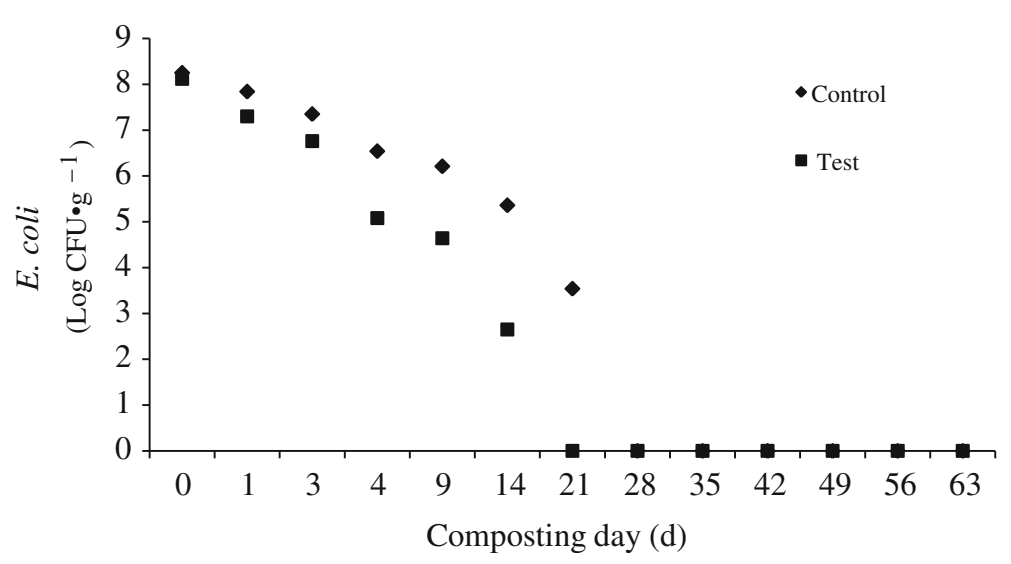

Fig. 7 The E. coli profile during composting 


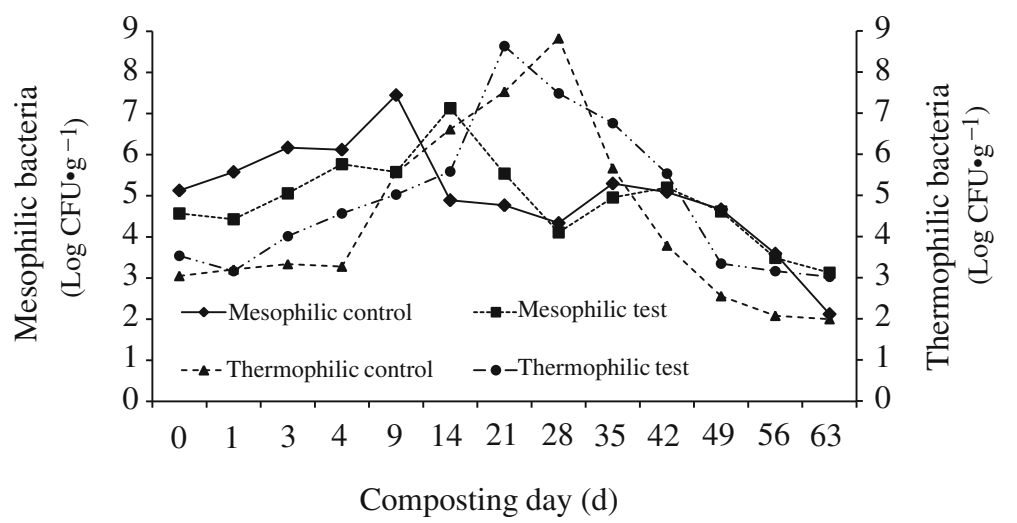

Fig. 8 The mesophilic and thermophilic bacteria profile during composting

in the control pile and 34.43 and $14.41 \%$ for thermophilic bacteria in the test pile. The decreasing rate of mesophilic bacteria was greater than thermophilic bacteria, which was related to the long thermophilic phase. The addition of $\mathrm{CaCN}_{2}$ did not significantly influence the total average population of mesophilic bacteria while increased that of thermophilic bacteria. It was because the longer and continuous thermophilic phase occurred in the test pile and the temperature was also much higher than the control pile (Fig. 8).

\section{Conclusions}

The work presented in this paper has demonstrated the feasibility of applying $\mathrm{CaCN}_{2}$ during minimally composting of manure with maize straw in a forced-aeration static-pile system. This provides a potential treatment process to improve the overall economic and environmental performance of manure recycling. The results of the investigation are summarised as follows.

(a) The time to reach the high temperatures was delayed but the maximum temperature increased and the duration of the thermophilic phase was lengthened with the addition of $\mathrm{CaCN}_{2}$.

(b) The environment suitable for composting process was not influenced by the addition of $\mathrm{CaCN}_{2}$.

(c) The addition of $\mathrm{CaCN}_{2}$ increased the percent T-N but decreased $\mathrm{C} / \mathrm{N}$ ratio during composting.

(d) With the addition of $\mathrm{CaCN}_{2}$, the phytotoxicity of the composting was decreased.

(e) The time to entirely inactivate $E$. coli in the composting could be shortened through adding $2 \%$ $\mathrm{CaCN}_{2}$ into the compostable substrate.

\section{Abbreviations}

$\mathrm{CaCN}_{2}$ : Calcium cyanamide; EMB: Eosin-methylene blue agar; Gl: Germination index; MB: Mesophilic bacteria; PVC: Perforated polyvinylchloride;

TB: Thermophilic bacteria; T-C: Total carbon; T-N: Total nitrogen; T-P: Total phosphorus

\section{Acknowledgement}

This work was supported by the Major Special Project of National Dairy Industry of China (grant number 2006BAD04A15), the Natural Science Foundation of Inner Mongolia Autonomous Region of China (grant number 202183), and the National Natural Science Funds, China (grant number 31060318).

\section{Funding}

The financial support in this study was mostly from the National Natural Science Funds, China (grant number 31060318). The Major Special Project of National Dairy Industry of China (grant number 2006BAD04A15) and the Natural Science Foundation of Inner Mongolia Autonomous Region of China (grant number 202183) provided the support for writing the manuscript.

Availability of data and materials

The datasets during and/or analysed during the current study are available from the corresponding author on reasonable request.

\section{Authors' contributions}

HS and CA are the main investigators, performed all experimental work and paper writing, CJW carried out data analysis, THZ carried out statistical analysis, BM provided all essential supports. All authors read and approved the final manuscript.

\section{Competing interests}

The authors declare that they have no competing interests.

\section{Consent for publication}

Not applicable.

Ethics approval and consent to participate Not applicable.

\section{Author details}

${ }^{1}$ College of Animal Science, Inner Mongolia Agricultural University, Zhaowuda road, 306, 010018 Hohhot, China. ${ }^{2}$ College of Veterinary Medicine, Inner Mongolia Agricultural University, Zhaowuda road, 306, 010018 Hohhot, China.

Received: 15 December 2015 Accepted: 3 October 2016 Published online: 26 October 2016

\section{References}

1. Gómez-Brandón M, Lazcano C, Domínguez J. The evaluation of stability and maturity during the composting of cattle manure. Chemosphere. 2008;70: 436-44.

2. Hutchison ML, Walters LD, Avery SM, Munro F, Moore A. Analyses of livestock production, waste storage, and pathogen levels and prevalences in farm manures. Appl Environ Microbiol. 2005;71:1231-6.

3. Parham J, Deng S, Raun W, Johnson G. Long-term cattle manure application in soil. Biol Fertil Soils. 2002;35:328-37. 
4. Fernández JM, Hernández D, Plaza C, Polo A. Organic matter in degraded agricultural soils amended with composted and thermally-dried sewage sludges. Sci Total Environ. 2007;378:75-80.

5. Wichuk KM, McCartney D. A review of the effectiveness of current timetemperature regulations on pathogen inactivation during composting. J Environ Eng Sci. 2007:6:573-86.

6. Berry ED, Millner PD, Wells JE, Kalchayanand N, Guerini MN. Fate of naturally occurring Escherichia coli O157: H7 and other zoonotic pathogens during minimally managed bovine feedlot manure composting processes. J Food Prot. 2013;76:1308-21.

7. Millner $P$, Ingram D, Mulbry W, Arikan OA. Pathogen reduction in minimally managed composting of bovine manure. Waste Manag. 2014:34:1992-9.

8. Bourbos VA, Skoudridakis MT, Darakis GA, Koulizakis M. Calcium cyanamide and soil solarization for the control of Fusarium solani f.sp. cucurbitae in greenhouse cucumber. Crop Prot. 1997;16:383-6.

9. Shi K, Wang L, Zhou YH, Yu YL, Yu JQ. Effects of calcium cyanamide on soil microbial communities and Fusarium oxysporum f. sp. Cucumberinum. Chemosphere. 2009;75:872-7.

10. Simujide $\mathrm{H}$, Aorigele C, Wang CJ, Manda B, Ma LN. Effect of calcium cyanamide on pathogenic Escherichia coli during mesophilic composting and impact on composting process. Global Nest J. 2012;14:460-7.

11. Bao SD. Soil and agricultural chemistry analysis (in Chinese). 3rd ed. Beijing: Agriculture Publishiling House; 2000.

12. Huang GF, Wong JWC, Wu QT, Nagar BB. Effect of C/N on composting of pig manure with sawdust. Waste Manag. 2004;24:805-13.

13. Zucconi F, Pera A, Forte M, De Bertoldi MARCO. Evaluating toxicity of immature compost. Biocycle. 1981;22:54-7.

14. Cohen MB, Nataro JP, Bernstein DI, Hawkins J, Roberts N, Staat MA. Prevalence of diarrheagenic Escherichia coli in acute childhood enteritis: a prospective controlled study. J Pediatr. 2005;146:54-61.

15. GB 7959-87. Sanitary standard for the non-hazardous treatment of night soil (in Chinese). 1988

16. Johannessen GS, James CE, Allison HE, Smith DL, Saunders JR, McCarthy AJ. Survival of a Shiga toxin-encoding bacteriophage in a compost model. FEMS Microbiol Let. 2005;245:369-75.

17. Sylla YB, Kuroda M, Yamada M, Matsumoto N. Feasibility study of a passive aeration reactor equipped with vertical pipes for compost stabilization of cow manure. Waste Manag Res. 2006;24:456-64.

18. Tang JC, Kanamori T, Inoue Y, Yasuta T, Yoshida S, Katayama A. Changes in the microbial community structure during thermophilic composting of manure as detected by the quinone profile method. Process Biochem. 2004; 39:1999-2006

19. Lung AJ, Lin CM, Kim JM, Marshall MR, Nordstedt R, Thompson NP, et al. Destruction of Escherichia coli 0157: H7 and Salmonella enteritidis in cow manure composting. J Food Prot. 2001;64:1309-14.

20. Larney FJ, Yanke $\amalg$, Miller JJ, McAllister TA. Fate of coliform bacteria in composted beef cattle feedlot manure. J Environ Qual. 2003:32:1508-15.

21. Changa CM, Wang P, Watson ME, Hoitink HAJ, Michel Jr FC. Assessment of the reliability of a commercial maturity test kit for composted manures. Compost Sci Util. 2003;11:127-45.

22. Fuentes B, Jorquera M, de la Luz Mora M. Dynamics of phosphorus and phytate-utilizing bacteria during aerobic degradation of dairy cattle dung. Chemosphere. 2009:74:325-31.

23. Takebayashi S, Narihiro T, Fujii Y, Hiraishi A. Water availability is a critical determinant of a population shift from Proteobacteria to Actinobacteria during Start-Up operation of mesophilic fed-batch composting. Microbes Environ. 2007:22:279-89.

24. Narihiro T, Abe T, Yamanaka Y, Hiraishi A. Microbial population dynamics during fed-batch operation of commercially available garbage composters. Appl Microbiol Biotechnol. 2004;65:488-95.

25. Narihiro T, Takebayashi S, Hiraishi A. Activity and phylogenetic composition of proteolytic bacteria in mesophilic fed-batch garbage composters. Microbes Environ. 2004;19:292-300

26. Nelson VL, Crowe TG, Shah MA, Watson LG. Temperature and turning energy of composting feedlot manure at different moisture contents in southern Alberta. Can Biosyst Eng. 2004:48:6.

27. Agnew JM, Leonard JJ. The physical properties of composting plants. Compost Sci Util. 2003:11:238

28. Rynk R. Monitoring moisture in composting systems. Biocycle. 2000;41:53-8.

29. Trémier A, Teglia C, Barrington S. Effect of initial physical characteristics on sludge compost performance. Bioresour Technol. 2009;100:3751-8.
30. Klasse H. Calcium cyanamide-an effective tool to control clubroot-a review. ISHS Brassica Symposium-IX Crucifer Genetics Workshop 407;1994

31. Wong JWC, Mak KF, Chan NW, Lam A, Fang M, Zhou LX, et al. Cocomposting of soybean residues and leaves in Hong Kong. Bioresour Technol. 2001;76:99-106.

32. El Fels L, Zamama M, El Asli A, Hafidi M. Assessment of biotransformation of organic matter during co-composting of sewage sludge-lignocelullosic waste by chemical, FTIR analyses, and phytotoxicity tests. Int Biodeter Bioderg. 2014;87:128-37.

33. Zeng GM, Huang DL, Huang GH, Hu T, Jiang X, Feng C. Composting of lead-contaminated solid waste with inocula of white-rot fungus. Bioresour Technol. 2007;98:320-6.

34. Smårs S, Gustafsson L, Beck-Friis B, Jönsson H. Improvement of the composting time for household waste during an initial low $\mathrm{pH}$ phase by mesophilic temperature control. Bioresour Technol. 2002;84:237-41.

35. Sundberg C, Smårs S, Jonsson H. Low pH as an inhibiting factor in the transition from mesophilic to thermophilic phase in composting. Bioresour Technol. 2004;95:145-50.

36. Green SJ, Michel FC, Hadar Y, Minz D. Similarity of bacterial communities in sawdust-and straw-amended cow manure composts. FEMS Microbiol Let. 2004;233:115-23.

37. Erickson MC, Liao J, Ma L, Jiang X, Doyle MP. Inactivation of Salmonella spp. in cow manure composts formulated to different initial C: $\mathrm{N}$ ratios. Bioresour Technol. 2009;100:5898-903.

38. Li G, Zhang F, Sun Y, Wong JWC, Fang M. Chemical evaluation of sewage sludge composting as a mature indicator for composting process. Water Air Soil Pollut. 2001;132:333-45.

39. Michel Jr FC, Pecchia JA, Rigot J, Keener HM. Mass and nutrient losses during the composting of dairy manure amended with sawdust or straw. Compost Sci Util. 2004;12:323-34.

40. Zhang Y, He Y. Co-composting solid swine manure with pine sawdust as organic substrate. Bioresour Technol. 2006;97:2024-31.

41. Parkinson $R$, Gibbs $P$, Burchett $S$, Misselbrook T. Effect of turning regime and seasonal weather conditions on nitrogen and phosphorus losses during aerobic composting of cattle manure. Bioresour Technol. 2004:91:171-8

42. Zucconi F, De Bertoldi M. Compost specifications for the production and characterization of compost from municipal solid waste. 1987.

43. Banegas V, Moreno JL, Moreno Jl, Garcia C, Leon G, Hernandez T. Composting anaerobic and aerobic sewage sludges using two proportions of sawdust. Waste Manag. 2007;27:1317-27.

44. Marcato-Romain CE, Pinelli E, Pourrut B, Silvestre J, Guiresse M. Assessment of the genotoxicity of $\mathrm{Cu}$ and $\mathrm{Zn}$ in raw and anaerobically digested slurry with the Vicia faba micronucleus test. Mutat Res Genet Toxicol Environ Mutagen. 2009:672:113-8.

45. Simujide H, Aorigele C, Wang CJ, Manda B, Lina M, Wu MY. Reduction of foodborne pathogens during cattle manure composting with addition of calcium cyanamide. Journal of Environ Eng Landsc. 2013;21:77-84.

46. Hellmann B, Zelles L, Palojarvi A, Bai Q. Emission of climate-relevant trace gases and succession of microbial communities during open-windrow composting. Appl Environ Microbial. 1997;63:1011-8.

47. Hassen A, Belguith K, Jedidi N, Cherif A, Cherif M, Boudabous A. Microbial characterization during composting of municipal solid waste. Bioresour Technol. 2001;80:217-25.

48. Nakasaki K, Sasaki M, Shoda M, Kubota H. Change in microbial numbers during thermophilic composting of sewage sludge with reference to $\mathrm{CO}_{2}$ evolution rate. Appl Environ Microbiol. 1985;49:37-41. 